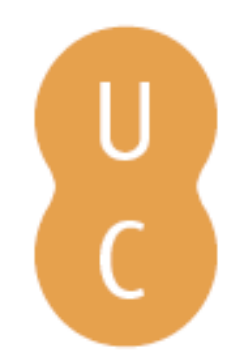

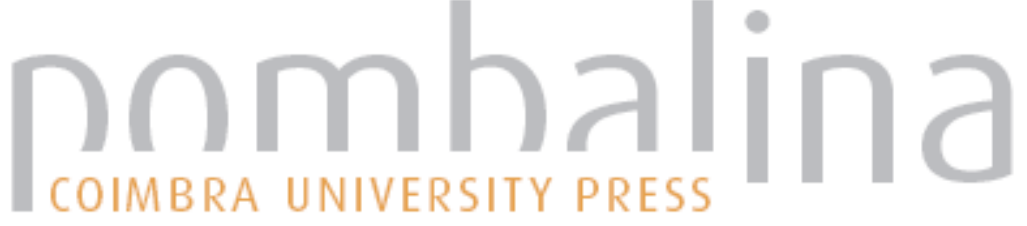

\section{Darwin, plants and Portugal}
Autor(es):
Paiva, Jorge

Publicado por: Imprensa da Universidade de Coimbra

URL persistente:

URI:http://hdl.handle.net/10316.2/31257

DOI:

DOI:http://dx.doi.org/10.14195/978-989-26-0342-1_4

Accessed : $\quad$ 26-Apr-2023 14:04:12

A navegação consulta e descarregamento dos títulos inseridos nas Bibliotecas Digitais UC Digitalis, UC Pombalina e UC Impactum, pressupõem a aceitação plena e sem reservas dos Termos e Condições de Uso destas Bibliotecas Digitais, disponíveis em https://digitalis.uc.pt/pt-pt/termos.

Conforme exposto nos referidos Termos e Condições de Uso, o descarregamento de títulos de acesso restrito requer uma licença válida de autorização devendo o utilizador aceder ao(s) documento(s) a partir de um endereço de IP da instituição detentora da supramencionada licença.

Ao utilizador é apenas permitido o descarregamento para uso pessoal, pelo que o emprego do(s) título(s) descarregado(s) para outro fim, designadamente comercial, carece de autorização do respetivo autor ou editor da obra.

Na medida em que todas as obras da UC Digitalis se encontram protegidas pelo Código do Direito de Autor e Direitos Conexos e demais legislação aplicável, toda a cópia, parcial ou total, deste documento, nos casos em que é legalmente admitida, deverá conter ou fazer-se acompanhar por este aviso.

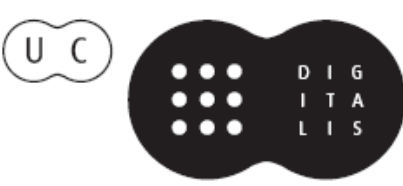


Ana Leonar Pereira João Rui Pita

Pedro Ricarda Fonseca (eds.)
Darwin,

Evalution,

Evolutionisms

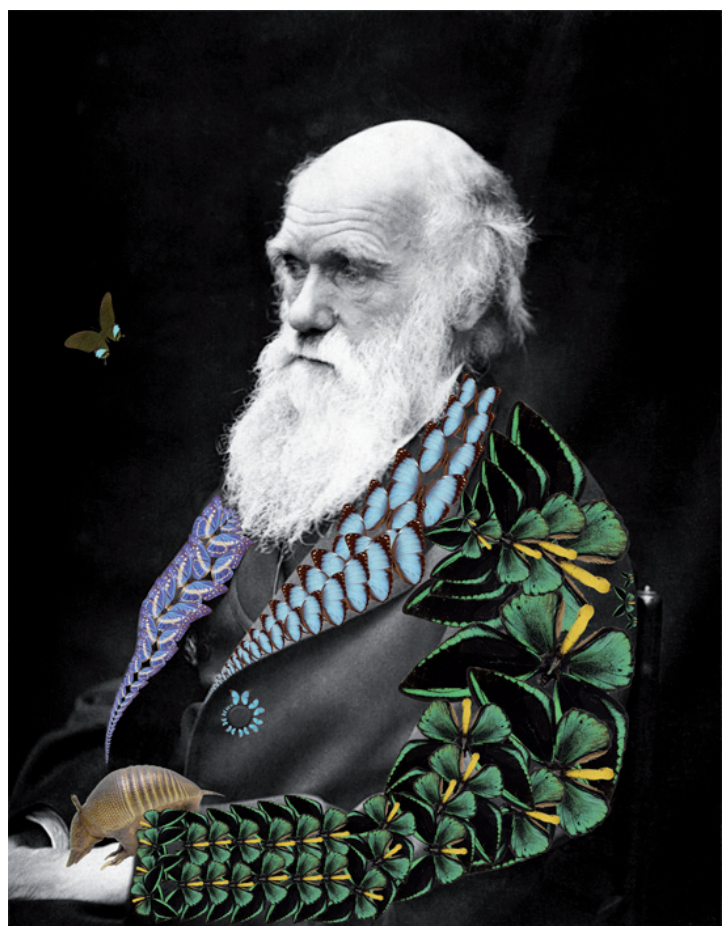




\section{Darwin, plants and Portugal}

\section{Introduction}

Charles Darwin's naturalist preparation started practically with his childhood education, roaming through the countryside, collecting insects, mineral shells and rocks. Still at a young age (16 years old), Darwin learned not only to observe and prepare plants as well as animals, when he went to the University of Edinburgh to study medicine. There he took the subject of Natural History taught by Robert Jameson and worked with the taxidermist John Edmonstone, a former slave, who taught him embalming. When, at the age of 18, he went to the University of Cambridge, the theoretical and practical preparation given to him by the professor of botany John Stevens Henslow, as well as the contacts he maintained throughout all his life with the botanists of the Royal Botanic Gardens of Kew, particularly with the respective Director, Joseph Dalton Hooker, were crucial for the botanical works he later developed.

Darwin did not simply collect plants during the voyage. He also herborised in Great Britain, so much so, that the oldest specimens collected by him are from August 1831, in Barmouth, Wales (Great Britain). It is a collection deposited in the Herberium of Christ's College [University of Cambridge (CGE)]

During the five year voyage, Darwin collected more than 2600 specimens of plants mounted on 950 herbarium sheets, arquived in the Herbarium of the University of Cambridge (CGE), not counting those collected in Great Britain and the small collections arquived in other Herbariums (BM; COL; E-GL; FI-W; GL; GOET; IH; $\mathrm{K}$; MANCH; MO; NY; OXF; P and U). Many of those specimens are type specimens of the various new species he collected.

Darwin did not herborise in an indiscriminated manner, although he declares that he did so in the Galapagos ("On the origin of species by means of natural selection, or the preservation of favoured races in the struggle for life";1859), for his notebooks are filled with botanical commentaries, as well as the books he published, some (seven) exclusively on plants.

The books he wrote on plants were a result not only of his literary culture (reading and sharing of opinions he made, in writing and orally, with various botanists and collectors), as well as from observations and experiences he did at his propriety in Down (Kent, England). Thus, he selectively cultivated (Artificial Selection) around 54 varieties of gooseberries and many of bean plants, pea plants and cabbages; he carried out interesting experiences, particularly with insectivorous plants; wrote essays 
on polinization; he studied the heterostyly of flowers of some plants; he conducted research on movements and nastic movements of plants, etc.

There are many species of fossils, animals, funghi, algae and plants, whose scientific names have restrictives as a tribute to Charles Darwin. In a list of scientific names of plants (sensu lato) dedicated to Darwin we elaborated, there are 6 fungi (currently included in the Kingdom of Mycota); 4 of algae (currently included in the Kingdom of Chromysta) and 88 in the Kingdom of Plantae [12 red algae (Rhodophyta), 1 green algae (Chlorophyta), 1 hepatica (Marchantiophyta), 4 Pteridophytes (2 Lycopodiophyta and 2 Polypodiophyta) and 70 Spermatophyta (Magnoliophyta)].

Charles Darwin (1809-1882) was a "Counter-Current", as was Nicolaus Copernicus (1473-1543) and Galileo Galilei (1564-1642). Copernicus ended with Aristotle's geocentrism, which got him convicted for going against the "Holy Scriptures" (Joshua 10: 13). Basically one century later, Galileo aggreeing with the heliocentrism modelled by Copernicus ("Revolution of the celestial spheres"; 1543), was convicted, having been forced, in his seventies, to abjure on his knees in the Court of the Roman Holy Office (Inquisition); Darwin ended up renouncing criationism (fixism) and antropocentrism based on the Biblical Genesis. Science showed that any one of them was right. The basic principles of evolutionism or darwinism, as Alfred Russell Wallace (1823-1913) called it in 1889, are currently well-established by various fields of Science (Biology, Geology, Biochemistry, Anatomy, Embryology, Paleonthology, Biogeography, Climatology, etc.) Evolutionism is not a theory but a natural phenomenon. With Genetics, Biochemistry and Molecular Biology it was confirmed that natural selection, which does not act (fenotipically) on the characters acquired, but through variations and genetic mutations are also extremely relevant evolutionary factors, as genetic recombinations, differential migrations, genetic derivatives and diverse mechanisms of isolation (neo-darwinism). Nowadays, with a better knowledge of symbiotic organisms it is considered that evolution occurs not only through competitive processes, but also cooperative, as is symbiogenesis (post-neodarwinism).

When Charles Darwin started the long voyage of the Beagle, he was a fixist, but when it ended, he was already a "transformist"; in other words, an evolutionist, as the diagram testifies ("evolutionary tree") that he designed in 1837 (6 months after returning to England), maybe based on the ramified structure of a corallinacea (Rhodophyta, red algae), probably Amphiroa orbignyana Decn.= Bossiella orbignyana (Decn.) P.C. Silva, he collected on the coasts of South America. It took many years to publish the first edition of The Origin of Species, not because of a fear of criticism and consequences, as it has been written and said many times, but because he wanted to be sure that he had confirmatory data that scientifically explained the "transmutations" (designation he attributed to specific variations). Natural Selection was the essence of all of his arguments.

Darwin was a researcher and tireless naturalist, without mentioning that, during the Beagle voyage, he collected 1529 species conserved in liquid, 3907 labelled and dry skins, as well as bones, fossils and about 2600 specimens of plants. Darwin was a scientist of great merit (he wrote more than a dozen books and more than two hundred articles), very cultured, having been careful not only to keep up to date with what he published on Earth Sciences, but also maintaining a constant dialogue and correspondence (he wrote around 14500 letters) with many contemporary scientists. 
As Darwin himself said, he was lucky to be a wealthy person, not needing to work to support his family, which gave him a lot of time for his investigations, as well as not losing time in meetings and activities of life in society, because he was always ill and rarely left home.

This is how Charles Darwin became an important figure, not only scientifically but also philosophically, having received many honours and awards during his lifetime, such as the doctorate Honoris Causa by the University of Cambridge, Honorary Professor of the Instituto Libre de Enseñanza Universitaria (Spain) and honorary member of 75 British and foreign Scientific Societies. Many statues were erected in his honour and his name was given to a city (Australia), an Institution for Scientific Research (Galapagos), a Botanical Institute (Argentina), a Natural Park (Australia), a Museum (Darwin Centre, Natural History Museum, London), geomorphological formations (Galapagos, South America and Tropical Africa), a scientific magazine (Darwiniana) and scientific epithet to many species and varieties of animals, plants and fossils. He was buried in Westminster Abbey, a few metres from Newton's grave.

\section{The plants}

Charles Darwin's naturalist preparation started practically with his childhood education, roaming through the countryside, collecting insects, mineral shells and rocks. Still at a young age (16 years old), Darwin learned not only to observe and prepare plants as well as animals, when he went to the University of Edinburgh to study medicine. There he took the subject of Natural History taught by Robert Jameson (1774-1854) and worked with the taxidermist John Edmonstone, a former slave, who taught him embalming (1825-1827). When, at the age of 18 , he went to the University of Cambridge, the theoretical and practical preparation given to him by the professor of botany John Stevens Henslow (1796-1861), was crucial for the botanical works he later developed. John Henslow not only granted him the practice for harvesting plants still in Cambridge, but also advised him during the Beagle voyage, in writing (letter 13.01.1833), not to collect fragments, but specimens which were the most complete ("perfect") as possible (roots, leaves and flowers). During the mentioned voyage, Darwin had an assistant (Syms Covington) not only for harvesting (collected birds and mammals, after 1833), but also for helping him in the last months of the expedition to prepare the lists of numbered plant specimens, ordered by taxonomic groups, to later distribute among the respective specialists. Finally, the constant contacts he maintained during his lifetime with botanists of the Royal Botanic Gardens of Kew, particularly with Joseph Dalton Hooker (1817-1911, director of Kew 1865-1885), the scientist to whom he first exposed in writing (letter dated 14th of July 1844) that he was convinced that the species were not fixed and that he had found the explanation for the process on how species adapted to the respective environments (here he did not use the term "Natural Selection"). This botanist studied a great part of the plants collected by Darwin during the Beagle voyage. Elucidatory of those contacts is what Darwin refers to in The Origin of Species ("On the origin of species by means of natural selection, or the preservation of favoured races in the struggle for life"; 1859) on the similarities that Joseph Hooker detected among the flora of the Kerguelen Island (located between South 
Africa and Australia) and New Zealand and Tierra del Fuego, and not with Africa's, much closer than Tierra del Fuego. At that time, nothing was known on the shift of continental plates and that South America had been connected to Australia and New Zealand. Thus, Darwin admitted that seeds had been transported by "icebergs" from the Land of Fire to New Zealand, as Charles Lyell (1797-1875), professor of geology at Cambridge suggested, who's "Principles of Geology" (1830) Darwin had read during the voyage (27.XII.1831 - 2.X.1836).

Darwin did not only collect plants during the voyage. He also herborised in Great Britain, so much so that the oldest specimens collected by him are from August 1831, in Barmouth, Wales (Great Britain), during the expedition that took place there, led by his Professor of Geology, Adam Sedgwick (1785-1873), at the University of Cambridge. It is a collection deposited in the Herbarium of Christ's College [University of Cambridge (CGE)], belonging to Matthiola sinuata (L.) R.Br., one Cruciferae (family of cabbages).

During the five-year voyage, Darwin collected more than 2600 specimens of plants mounted on 950 herbarium sheets, in the Herbarium of the University of Cambridge (CGE), not counting those collected in Great Britain and the small collections in other Herbariums (BM; COL; E-GL; FI-W; GL; GOET; IH; K; MANCH; MO; NY; OXF; $\mathrm{P}$ and $\mathrm{U}$ ). Many of those specimens are taxonomical types of the various new species he collected.

Darwin did not herborise in an indiscriminated manner, although he declares he did so in the Galapagos ("On the origin of species by means of natural selection, or the preservation of favoured races in the struggle for life"; 1859), for his notebooks are filled with botanical commentaries, as well as the books he published, some exclusively on plants, such as "On the contrivances by which British and foreign orchids are fertilised by insects" (1862 and 1877, 2nd ed.); "On the movements and habits of climbing plants" (1865-1882); "The variation of animals and plants under domestication" (1868 and 1875, 2nd ed.); "Insectivorous Plants" (1875 and 1888, 2nd ed.); "The effects of cross and self fertilisation in the vegetable kingdom" (1876 and 1878, 2nd ed.); "Different forms of flowers" (1877); "The power of movement in plants" (1880).

The specimens of the herbarium of plants collected by Darwin in the Galapagos, form the first scientific plant collection of that archipelago. Although there were Scientific Expeditions to the Galapagos before the Beagle, in 1835 (Archibald Menzies, in 1795; David Douglas and John Scoulter, in 1825; James MacRae, in 1825; Hugh Cumming, in 1829), Darwin's collection was the largest and most representative. All these collections were studied by Joseph Hooker (he established 114 new taxa for science), except Archibald's collection, the first naturalist to visit the Archipelago. Some authors comment that the expedition of Malaspina, between 1789 and 1794 and sponsored by King Charles III of Spain, was the first scientific expedition to the Galapagos, but there are no confirmatory documents of that fact. Nowadays, around 500 native species are referenced in this Archipelago, of which 180 (240 taxa) are endemic, and about 900 introduced. Darwin collected 290 numbered specimens of plants in the Galapagos, which he sent to the professor that had taught him to collect and prepare plants for herbarium (John Stevens Henslow). Initially, he tried to study them, being actually the first known scientific name for a plant in the Galapagos (1837) of John Henslow's authorship (Opuntia galapageia Hensl.), having dedicated another to Darwin [Opuntia darwinii Hensl. = Maihueniopsis darwinii (Hensl.) F. Ritter]. 
Later on, Joseph Hooker, at that time Director of the Royal Botanic Gardens in Kew, was in charge of carrying out that study, having described, in 1843, his first species of the Galapagos. This botanist described 78 new taxa, from material collected by Darwin, and 8 species dedicated to him [Abutilon darwinii Hook. f.; Chiliotrichum darwinii Hook. f. = Nardophyllym darwinii (Hook. f.) A. Gray; Eugenia darwinii Hook. f. = Pseudocaryophyllus darwinii (Hook. f.) Burret; Galapagoa darwinii Hook. f. = Tiquilia darwinii (Hook. f.) A.T. Richardson; Hymenophyllum darwinii Hook. f.; Pleuropetalum darwinii Hook. f.; Scalesia darwinii Hook. f.; Urtica darwinii Hook. f.] and a variety of [Conferva clavata C.Agardh var. darwinii Hook. f. \& Harv. = Chaetomorpha coliformis (Mont.) Kütz.].

William Jackson Hooker (1785-1865), father of Joseph Dalton Hooker, previous Director of the Royal Botanic Gardens in Kew (1841-1865), also studied some of the material collected by Darwin, and dedicated to him five species [Baccharis darwinii Hook. \& Arn. = Neomolina darwinii (Hook. \& Arn.) F. Hellweg; Berberis darwinii Hook.; Neosparton darwinii Benth. \& Hook. = Lippia darwinii (Benth. \& Hook.) Speg.; Panargyrus darwinii Hook. \& Arn. = Nassauvia darwinii ( Hook. \& Arn.) O. Hoffm. \& Dusé; Senecio darwinii Hook. \& Arn.].

Darwin was a shrewd observer, as is notorious in any of his botanical works. His prediction on the type of butterfly that was the pollinator of the big white flowers of the orchid Angraecum sesquipedale Thouars, which James Bateman (1811-1897), a wealthy collector of orchids, had sent him in January 1862, is famous. This orchid is endemic to Madagascar (Darwin did not see this orchid on the island, as many authors mention, since the Beagle never docked in Madagascar). Darwin, in Chapter $\mathrm{V}$ of the mentioned book on fertilisation of orchids by insects ( $O n$ the contrivances by which British and foreign orchids are fertilised by insects") predicted, not only that the butterfly that pollinated this species was nocturnal, but also that it had to have an extraordinarily long proboscis, since this flower has a spur of about $30 \mathrm{~cm}$, at the end of which is the nectar. Thus he says "...The pollinia are collected by a big nocturnal butterfly, possessing a magnificently long proboscis....” Besides that, he predicted not only that the butterfly was also a Malagasy endemic, as well as an interdependency between the two species (co-evolution or "correlated variation", as he called it) "... the disappearence of Angraecum would probably be a loss of these lepidoptera." About 40 years later, in 1903, Lionel Rothschild and Karl Jordam discovered, in Madagascar, the mentioned pollinating butterfly of the Angraecum sesquipedale Thouars, with the long proboscis, which they scientifically baptised with the epithet referring to the Darwinian prediction: Xanthopan morganii-praedicta Rothsch. \& Jord. As a matter of fact, the prediction made by Darwin was used by criationists to fight his evolutionist ideas. Thus, five years after Darwin made the mentioned prediction public, George Campbell published a book ("The Reign of Law"; 1867), in which it is said that a species like this, implicated having been raised by a supernatural being.

The books he wrote on plants were a result, not only of his literary culture (reading and sharing opinions he made, in writing and orally, with various botanists and collectors), but also from observations and experiences he prepared in his propriety in Down. Thus, he selectively cultivated (Artificial Selection) around 54 harvests of gooseberries (Ribes spp.) and many bean plants (Phaseolus spp.), pea plants (Pisum spp.) and cabbages (Brassica spp.). He performed interesting experiences, particularly 
with insectivorous plants, as he describes with Drosera rotundifolia L. ("Insectivorous Plants"), placing, among other products, small pieces of meat on the leaves: with the leaves as a trap on the Dionaea muscipula Ellis, whose leaves he considered caught insects just as mouse traps in "costilha" (backbreaker); with the leaves on the Pinguicula lusitanica L. (it exists not only in Portugal, but also in the British Isles, France and Spain, having Darwin obtained living plants on Cornwall, England), that roll to capture insects; he wrote essays on auto-polinization and crossed polinization such as the ones described with Linaria vulgaris Mill. ("The effects of cross and self fertilisation...), a Scrophulariaceae (family of the snapdragon) and with orchids ("On the contrivances..."); he studied heterostyly of the flowers of some plants, for example, the Lythrum salicaria L., purple loosestrife, and Primula vulgaris Huds., primrose ("Different forms of flowers"); he conducted research on understanding movements and nastic movements of plants ("On the movements and habits of climbing plants") and ("The power of movement in plants"); etc.

Darwin was concerned on studying vegetable activities with living plants, a topic that interested him. Thus, not only did he plant them in his farm in Down, where he even had greenhouses for plants that needed them, but he also tried, by every means, to find someone that could send him the living plants he wanted. He knew that in Portugal there existed an unusual insectivore plant, the Drosophyllum lusitanicum L. At that time it was thought that it was only found in Portugal, but today we know that this insectivore does not only exist in our country, but also in the Southwest of Spain and the Northwest of Africa. He asked Joseph Hooker, Director of the Royal Botanic Gardens in Kew, to ask for plants of that species from the Directors of the Botanical Gardens of Portugal [at that time there were two Gardens of that kind in our country: the Royal Garden of Ajuda and the Botanical Garden of Coimbra, whose Director was António José Rodrigues Vidal (1868-1872)], but Joseph Hooker never received an answer. However, on January 26th, 1869, Darwin received a letter from William Chester Tait (1844-1921), a British enologist and amateur botanist, resident and owner of a farm in Porto (Casa Tait, Quinta do Meio, currently propriety of the Town-hall of Porto), in which he questioned him on the heredity of dogs with docked tails (19.02.1869). Darwin, in his reply (24.02.1869), said that he was not interested in the issue of dog tail mutilation and respective transmission or not. However, he took the opportunity to ask William Tait if he could send him living plants of Drosophyllum lusitanicum L. William Tait sent him the first sample (02.03.1869), together with a piece of a fern leaf that he had seen at the location where he had collected the insectivore plant (Monte de Santa Justa, Valongo), so that Darwin could tell him what kind of fern it was (concluding that it would be Culcita macrocarpa K. Presl, a very robust fern, that is only seen in Portugal and is not cited in Flora Lusitanica de Brotero, that W. Tait possessed, as he mentions in that letter). Darwin answered him (12 and 16.03.1869), saying that he did not know the fern, confirming and thanking the reception of the Drosophyllum lusitanicum L. William Tait sent more samples (living and in containers) of the insectivore plant (they exchanged amongst themselves 18 letters each - between 19.02 and 29.09.1869), with some "curious" information, such as the fact that the local population put these plants in the balconies of houses to catch flies. He even said that the locals called it "erva-apanha-moscas" (fly-catching grass), common name which is not currently used for this species, which is known as Portuguese sundew or dewy pine. 

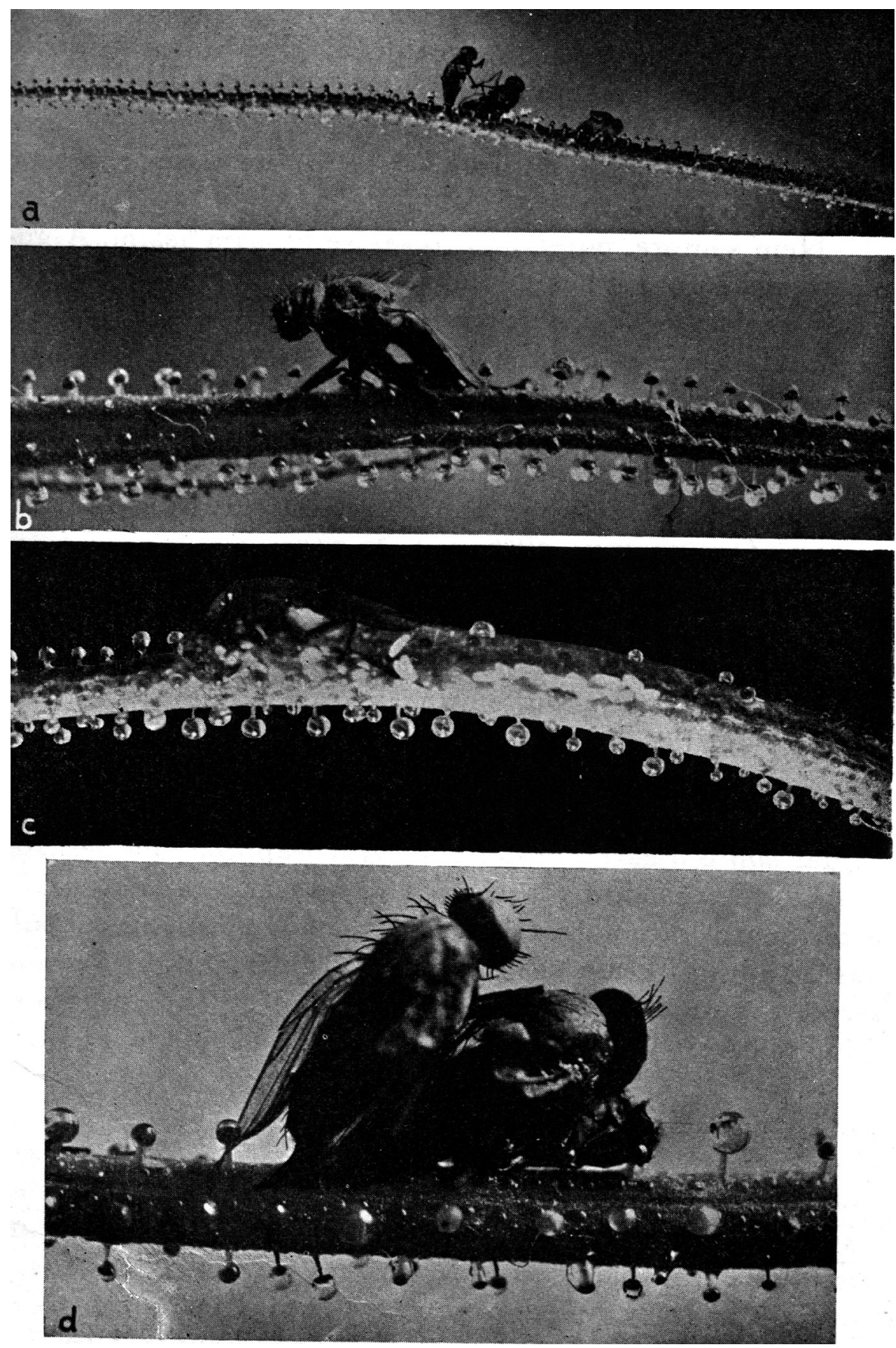

Flies caught in the leaves of Drosophyllum lusitanicum

Foto in: Abílio Fernandes, 1941. Morfologia e Biologia das Plantas Carnívoras.Separata do Anuário da Sociedade Broteriana, Anos VI e VII 
In his publication on the Beagle voyage ("Journal of researches into the natural history and geology of the countries visited during the voyage of H.M.S. Beagle round the world."; 1839) there are incredible botanical observations, still valid nowadays, such as those referring to the endemic flora of the Galapagos: "If we take a look now at the flora we will discover that the aboriginal plants of the different islands are surprisingly different. I present the set of the following results having the support of the solid authority of my friend Dr J. Hooker. I have to anticipate that I indiscriminately collected all the flowers found in the different islands and that due to luck I kept my collections separate... However, my drawings show the amazing fact that in James Island, of the thirty eight Galapagan plants or those that cannot be found anywhere else in the world, thirty are exclusively confined to this island; and at Albemarle Island, of the twenty six aboriginal galapagan plants, twenty two are confined to it; this is, they are only known until today to be grown on other islands of the archipelago; and so forth...The Scalesia, an incredible arborescent genus of the Compositae, is confined to the Archipelago. It has six species; one of Chatham, one of Albemarle, one of Charles Island, two from James Island and a sixth of one of the last three islands...none of these six species is grown on two islands." Or yet its American origin: "Dr. Hooker lets me know that the flora has an undoubtedly American western character; in the same way, he does not detect any affinity with the Pacific flora." In reality, all that can be confirmed, being Scalesia Hook. f. a endemic genus of the Galapagos, with 6 species, 5 of Joseph Hooker's authorship (S. affinis Hook. f., S. darwinii Hook. f., S. gummifera Hook. f., S. incisa Hook. f. e S. pedunculata Hook. f.) and 1 of G. Arnott (S. atractyloides Arn.), all tipified by specimens collected by Darwin.

The research for a plausible explanation on the way plants colonized the oceanic islands was one of his concerns, as he notes in some publications, like "Journal of researches into the natural history and geology of the countries visited during the voyage of H.M.S. Beagle around the world." "Thus, the flora of Madeira resembles, to a certain degree, the tertiary flora extinct in Europe." and in some letters, like the answer sent to the Azorean Francisco Arruda Furtado, with dated 3rd of July 1881 "If it were possible, I would visit and collect in one or various of the furthest islands and would compare the plants and animals with the other islands...Samples should be collected from all plants and animals from the highest points of the mountains of all them... Is there a lighthouse in the Azores? If there is, probably there are sometimes birds that fly against the window and die. If so, it would be advisable to examine not only their feet and beaks searching for dirt, but also remove all the content from the food channels and observe the existence of seeds that might germinate. If that happens, let the plants grow and identify them..Does the sea usually drag trees with roots to the shore? If so, the roots should be separated and any trace of earth among them, should be washed and placed in burnt earth and moistened in pure sand, under a glass canopy, in order to observe if the earth has any living seeds... After very strong winds, it might be worth it to look among the rubbish thrown on the shore, seeds, insects, etc."

Darwin exchanged letters with only one Portuguese person, Francisco Arruda Furtado (1854-1887) and it was at the end of his life (1881). Francisco Arruda was a scribe from the Azores and an amateur malacologist, that decided to write (13.06.1881) to Darwin, after reading his famous work "On the origin of species by means of natural selection, or the preservation of favoured races in the struggle for life" 
(1859) and knowing that Darwin had a special interest in the study of Mollusks. In his answer (03.07.1881), Darwin, besides other recommendations, such as reading Alfred Russel Wallace's work, advised him to collect plants from the mountains and all the vegetable testimonies (roots, trunks) that came upon the Azorean shores, because they could help understand how the colonization happened, for plants in the Archipelago. In the scarce correspondence they exchanged (10 letters), Francisco Arruda, in one of the letters (29.07.1881), announced that he was going to send him seeds of 3-4 species, collected from the coasts of the island, dragged by the Gulf Current, that fisherman used as table decorations and emptied the biggest which they called "favas-do-mar" (sea broad lean), to make snuff boxes. In August (17.08.1881), Francisco Arruda asked Darwin to who he sent two small herbariums of plants collected in the mountains [Serra Gorda and Pico da Cruz (Pico da Pedra)] and said that he could not buy Wallace's work, which Darwin had recommended (13.07.1881) to read, because it was too expensive. Darwin announced (02.09.1881) that he sent Wallace's work by post, a work which he offered him. A few days later (12.09.188), Darwin told Francisco Arruda that he should send the plants to J. Hooker (providing him the address), who appeared to be very interested and advised him to investigate the existence of big cypress trunks that were found buried in the soil of the Azorean mountains, because they were considered extinct. These trunks were, most probably, of Juniperus brevifolia (Seub.) Antoine, the cedar of the Azores, an endemic species of this Archipelago, currently rigorously protected. Darwin never accused the reception of the seeds, maybe because he did not have time to study them or because Francisco Arruda never sent them. According to Francisco Arruda's description, it is possible to identify them, since they are seeds of trees from the African Tropical coast, dispersed by the Warm Current of the Gulf which hit azorean shores. The ones Francisco Arruda said were being used by Azorean fishermen for snuff boxes are huge seeds of the Leguminosae species, of the group of Mimosoideae, belonging to the genus Entada Adans., which have pods that reach 1,80 metres long and seeds ("favas-do-mar") diameters of $4-5 \mathrm{~cm}$. Due to the geographical position of the Azores, it probably would have been seeds of Entada pursaetha DC. or Entada gigas Fawc. \& Rendel, two species which are found in the Western coast of Tropical Africa and the Eastern coast of Tropical America. Seeds of these species have recently appeared at the coast of Continental Portugal, from the South to Praia da Barra (Aveiro), which indicates the dislocation of the Warm Current of the Gulf further North, due to "Global Warming". The other seeds, much smaller (no longer than a broad bean), that Francisco Arruda said are used as decoration objects, are seeds of Leguminosae, also from the group of Mimosoideae, belonging to the genus Dioclea Kunth, equally trees of the tropical coast that are still used today as ornaments, particularly necklaces. For the reasons mentioned for the species of Entada Adans., probably seeds of Dioclea reflexa Hook. f. or Dioclea megacarpa Rolfe.

In a description like this, it is not possible to refer to all the observations and studies that Darwin did with plants, which were many, although he studied and published more, on geology and zoology.

There are many species of fossils, animals, funghi and plants, whose scientific names have specific restrictives or varieties as a tribute to Charles Darwin. As I am a botanist, I present a list of scientific names of plants dedicated do Darwin. 


\section{NAMES OF “PLANTS” DEDICATED TO DARWIN}

Kingdom MYCOTA (Fungi)

\section{Ascomycota}

Cyttaria darwinii Berk.

Darwiniella Spegg.

Darwiniella antarctica Spegg.

Darwiniella globulosa (Cooke \& Massee) Sacc.

Dothidea globulosa Cooke \& Massee

Darwiniella gracilis (Spegg.) Spegg.

Dothidea gracilis Spegg.

Darwiniella orbiculata Syd.

\section{Kingdom CHROMISTA (Algae)}

\section{Bacillariophyta}

Asterolampra darwinii (Ehrenb.) Grev.

Asteromphalus darwinii Ehrenb.

Asteromphalus darwinii Ehrenb. = Asterolampra darwinii (Ehrenb.) Grev.

\section{Ochrophyta}

Distephanopsis crux (Ehrenb.) Dumitrica subsp. darwinii (Bukry) Desikachary \& Prema Distephanus crux (Ehren.) Haeckel subsp. darwinii Bukry Distephanus crux (Ehren.) Haeckel subsp. darwinii Bukry = Distephanopsis crux (Ehrenb.) Dumitrica subsp. darwinii (Bukry) Desikachary \& Prema

Kingdom PLANTAE

Algae

Rhodophyta

Amphiroa darwinii Harv. = Bossiella chiloensis (Decne.) H.W. Johans.

Arthrocardia darwinii (Harv.) Weber Bosse = Bossiella chiloensis (Decne.) H.W. Johans. 
Amphiroa darwinii Harv.

Botryocladia darwinii C.W.Schneid. \& C.E. Lane

Chaetomorpha darwinii (Hook. f. \& Harv.) Kütz. = Chaetomorpha coliformis (Mont.) Kütz.

Conferva clavata C.Agardh var. darwinii Hook. f. \& Harv.

Cheilosporum darwinii (Harv.) De Toni = Bossiella chiloensis (Decn.) H.W. Johans.

Amphiroa darwinii Harv.

Conferva clavata C.Agardh

var. darwinii Hook. f. \& Harv. = Chaetomorpha coliformis (Mont.) Kütz.

Conferva darwinii (Hook. f. \& Harv.) Harv. = Chaetomorpha coliformis (Mont.) Kütz.

Conferva clavata C.Agardh var. darwinii Hook. f. \& Harv.

Goniolithon darwinii (Harv.) Foslie = Lithothamnion darwinii (Harv.) Foslie

Melobesia darwinii Harv

Lithophyllum darwinii (Harv.) Foslie = Lithothamnion darwinii (Harv.) Foslie

Melobesia darwinii Harv Kütz.

Lychaete darwinii (Hook. f. \& Harv.) Laing = Chaetomorpha coliformis (Mont.)

Conferva clavata C.Agardh var. darwinii Hook. f. \& Harv.

Lithothamnion darwinii (Harv.) Foslie

Melobesia darwinii Harv

Melobesia darwinii Harv. = Lithothamnion darwinii (Harv.) Foslie

\section{Chlorophyta}

Pediastrum darwinii Haeckel

Bryophyte (Non-vascular)

Marchantiophyta

Frullania darwinii Gradst. \& Uribe

\section{Cormophyta (Vascular)}

Lycopodiophyta

Huperzia darwiniana (Herter ex Nessel) B. Ollg.

Urostachys darwinianus Herter ex Nessel 
Urostachys darwinianus Herter ex Nessel = Huperzia darwiniana (Herter ex Nessel) B. Ollg.

Polypodiophyta

Hymenophyllum darwinii Hook. f.

Thelypteris darwinii L.D. Gómez

\section{Magnoliophyta}

Abutilon darwinii Hook. f. (Malvaceae)

Acmella darwinii (D.M. Porter) R.K. Jansen (Asteraceae)

Spilanthes darwinii D.M. Porter

Allochlamys darwinii Moq. = Pleuropetalum darwinii Hook. f. (Amaranthaceae) Asteriscus vogelii (Webb) Walp.

var. darwinii (Webb) Walp. = Nauplius daltonii (Webb) Wiklund subsp. vogeliii

(Webb) Wiklund (Asteraceae)

Astragalus darwinianus Gómez-Sosa (Fabaceae)

Baccharis darwinii Hook. \& Arn. = Neomolina darwinii (Hook. \& Arn.) F. Hellweg (Asteraceae)

Berberis darwinii Hook. (Berberidaceae)

Bonatea darwinii Weale = Bonatea cassidea Sond. (Orchidaceae)

Calceolaria darwinii Benth. = Calceolaria uniflora Lam. (Scrophulariaceae)

Fagelia darwinii (Benth.) Kuntze

Carex darwinii Boott (Cyperaceae)

Catasetum darwinianum Rolfe (Orchidaceae)

Chiliotrichum darwinii Hook. f. = Nardophyllym darwinii (Hook. f.) A. Gray (Asteraceae)

Clinopodium darwinii (Benth.) Kuntze (Lamiaceae)

Micromeria darwinii Benth.

Satureja darwinii (Benth.) Briq.

Coldenia darwinii (Hook. f.) A. Gray = Tiquilia darwinii (Hook. f.) A.T. Richardson (Boraginaceae)

Galapagoa darwinii Hook. f.

Croton scouleri Hook. f.

var. darwinii G.L. Webster (Euphorbiaceae)

Darwinia Raf. (1817) = Sesbania Scop. (Fabaceae $)$ dedicated to his Grandfather, Erasmus Darwin

Darwinia Dennst. $(1818)=$ Litsea Lam. (Lauraceae) dedicated to his Grandfather, Erasmus Darwin

Darwinia Rudge (1816) (Myrtaceae)dedicated to his Grandfather, Erasmus Darwin

Darwiniella Braas \& Lückel = Stellilabium Schltr. (Orchidaceae)

Darwiniera Braas \& Lückel (Orchidaceae)

Darwiniera bergoldii (Garay \& Dunst.) Braas \& Lückel (Orchidaceae)

Trichoceros bergoldii Garay \& Dunst. 
Darwiniothamnus Harling (Asteraceae)

Darwiniothamnus alternifolius Lawesson \& Adsersen (Asteraceae)

Darwiniothamnus lancifolius (Hook. f.) Harling (Asteraceae)

Erigeron lancifolius Hook. $\mathrm{f}$

Darwiniothamnus lancifolius (Hook. f.) Harling (Asteraceae)

Erigeron tenuifolius Hook. $\mathrm{f}$.

Decalophium darwioniodes Turcz. = Chamelaucium ciliatum Desf. (Myrtaceae)

Drosera darwinensis Lowrie (Droseraceae)

Eucalyptus darwinensis D.J. Carr \& S.G.M. Carr (Myraceae)

Eugenia darwinii Hook. f. = Pseudocaryophyllus darwinii (Hook. f.) Burret (Myraceae)

Eustephia darwinii Vargas (Amaryllidaceae)

Fagelia darwinii (Benth.) Kuntze = Calceolaria uniflora Lam. (Scrophulariaceae)

Galapagoa darwinii Hook. f. = Tiquilia darwinii (Hook. f.) A.T. Richardson (Boraginaceae)

Garcinia darwiniana Kesh. Murthy, Yogan. \& Vasud. Nair (Clusiaceae)

Gossypium barbadense L.

Var. darwinii (Watt) J.B. Hutch. (Malvaceae)

Gossypium darwinii Watt

Gossypium darwinii Watt = Gossypium barbadense L. var. darwinii (Watt) J.B. Hutch. (Malvaceae)

Hebe darwiniana (Colenso) Wall. (Scrophulariaceae)

Veronica darwiniana Colenso

Homoranthus darwinioides (Maiden \& Betche) Cheel = Rylstonea darwinioides

(Maiden \& Betche) R.T. Baker (Myrtaceae)

Verticordia darwinioides Maiden \& Betche

Hoya darwinii Loher (Asclepiadaceae)

Laeliocatlleya x darwiniana Hort. (Orchidaceae)

Lagopsis darwiniana Pjak (Lamiaceae)

Lecocarpus darwinii Adsersen (Asteraceae)

Lippia darwinii (Benth. \& Hook.) Speg. (Verbenaceae)

Neosparton darwinii Benth. \& Hook.

Maihueniopsis darwinii (Hensl.) F. Ritter (Cactaceae)

Opuntia darwinii Hensl.

Tephrocactus darwinii (Hensl.) Backeb.

Micromeria darwinii Benth.= Clinopodium darwinii (Benth.) Kuntze (Lamiaceae)

Myrtus darwinii Barnéoud (Myrtaceae)

Nardophyllym darwinii (Hook. f.) A. Gray (Asteraceae)

Chiliotrichum darwinii Hook. f.

Nassauvia darwinii ( Hook. \& Arn.) O. Hoffm. \& Dusén (Asteraceae)

Panargyrus darwinii Hook. \& Arn.

Neomolina darwinii (Hook. \& Arn.) F. Hellweg (Asteraceae)

Baccharis darwinii Hook. \& Arn.

Neosparton darwinii Benth. \& Hook. = Lippia darwinii (Benth. \& Hook.) Speg. (Verbenaceae)

Odontospermum vogelii Webb 
var. darwinii Webb = Nauplius daltonii (Webb) Wiklund subsp. vogeliii (Webb) Wiklund (Asteraceae)

Opuntia darwinii Hensl. = Maihueniopsis darwinii (Hensl.) F. Ritter (Cactaceae) Oxalis darwinii Ball (Oxalidaceae)

Panargyrus darwinii Hook. \& Arn. = Nassauvia darwinii (Hook. \& Arn.)

O. Hoffm. \& Dusé (Asteraceae)

Pandanus darwinensis H.St. John (Pandanaceae)

Pisonia darwinii Hemsl. (Nyctaginaceae)

Pleuropetalum darwinii Hook. f. (Amaranthaceae)

Poa darwiniana Parodi (Poaceae)

Polygala darwiniana A.W Benn. (Polygalaceae)

Pseudocaryophyllus darwinii (Hook. f.) Burret (Myraceae)

Eugenia darwinii Hook. f.

Rumex darwinianus Rchb. f. (Polygonaceae)

Rylstonea darwinioides (Maiden \& Betche) R.T. Baker (Myrtaceae)

Verticordia darwinioides Maiden \& Betche

Homoranthus darwinioides (Maiden \& Betche) Cheel

Satureja darwinii (Benth.) Briq. = Clinopodium darwinii (Benth.) Kuntze (Lamiaceae)

Micromeria darwinii Benth.

Scalesia atractyloides Arn.

var. darwinii (Hook. f.) Eliason. = Scalesia darwinii Hook. f. (Asteraceae)

Scalesia darwinii Hook. f. (Asteraceae)

Senecio darwinii Hook. \& Arn. (Asteraceae)

Siegfriedia darwinioides C.A. Gardner (Rhamnaceae)

Spilanthes darwinii D.M. Porter = Acmella darwinii (D.M. Porter) R.K. Jansen (Asteraceae)

Tephrocactus darwinii (Hensl.) Backeb. = Maihueniopsis darwinii (Hensl.)

F. Ritter (Cactaceae)

Opuntia darwinii Hensl.

Tiquilia darwinii (Hook. f.) A.T. Richardson (Boraginaceae)

Galapagoa darwinii Hook. f.

Coldenia darwinii (Hook. f.) A. Gray

Urtica darwinii Hook. f. (Urticaceae)

Veronica darwiniana Colenso = Hebe darwiniana (Colenso) Wall. (Scrophulariaceae)

Verticordia darwinioides Maiden \& Betche = Rylstonea darwinioides (Maiden \&

Betche) R.T. Baker (Myrtaceae)

Zinnia x darwinii Haage \& Schmidt (Asteraceae) 